\title{
Stand and coarse woody debris dynamics in subalpine Norway spruce forests withdrawn from regular management*
}

\author{
Renzo MotTA $^{1 * *}$, Roberta BerRetti ${ }^{1}$, Daniele CASTAGNERI $^{1}$, Emanuele LinguA $^{2}$, Paola NolA $^{3}$, \\ Giorgio VACCHIANO ${ }^{1}$ \\ ${ }^{1}$ University of Turin, Dep. Agroselviter, Via Leonardo da Vinci 44, 10095 Grugliasco (TO) Italy \\ ${ }^{2}$ University of Padua, Italy \\ ${ }^{3}$ University of Pavia, Italy
}

(Received 16 November 2009; accepted 1 May 2010)

Keywords:

competition /

coarse woody debris (CWD) /

stand density index (SDI) /

age structure /

old-growth

\begin{abstract}
- We studied structural characteristics, amount and quality of coarse woody debris (CWD), intensity of competition and mortality in two subalpine Norway spruce stands withdrawn from regular management. The stands, that we measured twice (in 1993 and 2005), have similar age and structure, but a different time has elapsed since the last silvicultural treatments (respectively 22 and about $55 \mathrm{y}$ ).

- The main purposes were to analyze the current stage of development as compared to the old-growth one and to highlight the legacies of past management.

- Although relatively old, the first plot (Valbona 1) was at the end of the pole stage. CWD was low in volume and was mainly of man-made origin (stumps). A recent thinning from below has reduced density-dependent competition and delayed the development of old-growth characteristics. The second plot (Valbona 2a) was at the beginning of the transition stage, with density-dependent and allogenic mortality both active at the same time. CWD volume was higher in plot Valbona 2a than in Valbona 1, but neither was comparable yet to the reference old-growth sites from Central Europe, both in quantity and in quality (e.g., decay rate continuity).

- The effects of the past management were: (1) reducing the quality and quantity of the CWD, (2) alleviating competition, (3) increasing resistance to minor disturbances and, as a consequence, (4) delaying the development processes.

- In mature or overmature subalpine Norway spruce stands withdrawn from regular management many decades are necessary to develop old-growth characteristics and a longer period of time is necessary to reach a true old-growth stage.
\end{abstract}

\section{INTRODUCTION}

Since the second half of the 19th century, in most of the Italian Alps the socioeconomic structure and the public attitude towards forests and forestry have dramatically changed, resulting in extensive land use changes and in a noticeable reduction in human activities (Motta et al., 2006). As a consequence, many forests have been withdrawn from regular silvicultural management and have developed without direct human influence (Vandekerkhove et al., 2009). At the same time, while the past management was concentrated on extracting products from the forest, the present and the future one should emphasize what is being left (Kohm and Franklin, 1997).

Stakeholders and foresters are increasingly aware of the unique characteristics and values that overmature, latesuccessional and old-growth forests (sensu Oliver and Larson,

* This manuscript issues from a presentation at the LWF conference, Zürich, September 2009.

**Corresponding author: renzo.motta@unito.it
1996) provide. Nevertheless, due to the past intensive management, early seral stages are over-represented and late seral stages are rare or even absent (Motta, 2002).

Old-growth forests are later stages in forest development that are compositionally and structurally distinct from earlier successional stages. The age at which stands develop oldgrowth characteristics varies widely according to forest type, climate, site conditions and disturbance regime, hence the existence of various degrees of old-growth condition. In general the processes that take place in old-growth forests imply certain structural characteristics with significant ecological and aesthetic values: large and old trees, the abundance of dead organic material (coarse woody debris or CWD) like logs and snags, and canopy gaps formed by fallen trees. Overmature or late-successional forests are at a stage of stand development preceding old-growth; they encompass some attributes of oldgrowth forests but lack other key old-growth characteristics (Foster et al., 1996). 
Due to the past human impact true old-growth stands no longer exist in the Italian Alps (Motta, 2002). On the other hand, there are many stands that have been withdrawn from regular management for decades. In these stands the natural processes, e.g., competition and disturbances, are superimposed on and interact with past human-induced changes. Such cultural legacy has important implications for the present-day structures and processes (Foster et al., 2003; Franklin et al., 2007).

Our specific questions were: (1) how long do old-growth characteristics take to develop from over-mature subalpine Norway spruce (Picea abies (L.) Karst.) forests that have been withdrawn from regular management respectively for 22 and $55 \mathrm{y}$ ? (2) Which are the legacies of the past management?

The results will provide baseline data to support the conservation and management of late successional Norway spruce subalpine forests, in order to recognize forest stands that deserve protection and to devise practices that will hasten the development of late-seral and old-growth characteristics, that are currently largely under-represented in the whole European Alps (Bauhus et al., 2009; Keeton, 2006; Marage and Lemperiere, 2005).

\section{MATERIALS AND METHODS}

\subsection{Study area}

The study area is located in the Valbona forest reserve (lat. $46^{\circ} 18^{\prime} \mathrm{N}$, long. $\left.11^{\circ} 45^{\prime} \mathrm{E}\right)$ that is part of the Paneveggio Forest at an elevation ranging from $1695 \mathrm{~m}$ for plot Valbona 1 (VB1) to $1815 \mathrm{~m}$ a.s.1. for plot Valbona 2a (VB2a). The bedrock is porphyry, partially covered by morainic material, and the soils are podsols and non calcareous lithomorphic soils. The forest type is "Typical subalpine Norway spruce".

The human presence in Paneveggio started in the Mesolithic age (8000 bp) and the forests of the Fiemme valley have been managed at least since the beginning of the XIII century. The Forest of Paneveggio has belonged to the Austro-Hungarian Empire until the end of the First World War. Since 1919, the forest has been property of the Italian State and since the 1970s of the Autonomous Province of Trento. Since 1990 it has been part of the "Parco Naturale Paneveggio-Pale di S. Martino". The Valbona forest reserve (123 ha) was established in 1992, and contains a silvicultural reserve for experimental research (43 ha) and a strict reserve ( $80 \mathrm{ha}$ ).

Most of the reserve is characterized by monolayered Norway spruce stands. In the most mature part of the reserve we selected two study areas according to a chronosequence in the human abandonment process, ranging from the recent end of the silvicultural treatments up to a few decades of abandonment. The disturbance history and, particularly, the cessation of silvicultural treatments was estimated in $22 \mathrm{y}$ for plot VB1 and about $55 \mathrm{y}$ for plot VB2a using release from suppression in cross-dated cores and validated using Management plans (Motta et al., 1999).

\subsection{Stand structure}

The size of the two permanent plots is, respectively, 10267 (VB1) and $14046 \mathrm{~m}^{2}$ (VB2a). The two plots were established and mapped in 1993 (Motta et al., 1999). In the initial inventory we recorded species, tree topographic coordinates and diameter at breast height (dbh) for all living trees $\geq 7.5 \mathrm{~cm}$ in $\mathrm{dbh}$. Total height, height to the lowest live branch in two opposite directions and crown projections on the ground in four directions were also measured. One core was extracted at $50 \mathrm{~cm}$ height from all living trees in 1995 . In the lab, following optimization of surface resolution, radial increments to the nearest $0.01 \mathrm{~mm}$ were measured and cross-dated against available and updated site chronologies (Motta et al., 2002).

The inventory was repeated in 2005 and tree lists were updated with ingrowth; dbh, heights and crown projections were re-measured and ingrowth cores were collected and cross-dated. Volume for living trees was calculated according to local yield tables. We tested (a) the normality of size distributions in the two plots by the Shapiro-Wilk test; (b) the statistical differences in paired data (size distribution in two different inventories and trees/CWD size distribution in the same plot) by a Wilcoxon non-parametric test and (c) the statistical differences in independent samples (size distribution in two different plots) by a Kolmogorov-Smirnov non-parametric test. Statistical analyses were performed using PAST 1.90 (Hammer et al., 2001).

\subsection{CWD (Coarse woody debris)}

We grouped CWD into snags (standing dead trees, dbh $\geq 7.5 \mathrm{~cm}$ and height $\geq 1.3 \mathrm{~m}$ ), downed logs (fallen stems or branches $\geq 7.5 \mathrm{~cm}$ diameter and length $\geq 1 \mathrm{~m}$ ) and stumps (short, vertical remains from cutting or windthrow, top diameter $\geq 7.5 \mathrm{~cm}$ and height $<1.30 \mathrm{~m}$ ). A stump was classified as man-made if the exposed surface was straight, indicating felling by saw. The separation of snags from logs was established at a $45^{\circ}$ angle. Volumes for non-broken snags were calculated according to methods described in Motta, Berretti et al. (2006). The decay stage (Tab. I) was classified according to a four-class system (Sollins, 1982). We extracted, prepared and cross-dated one core from snags and logs in decay classes 1 and 2.

\subsection{Competition and mortality}

We assessed crowding in plot VB1 and plot VB2a by means of Reineke's (1933) Stand Density Index (SDI), using the summation method proposed by Shaw (2000). Relative density, i.e., the percent ratio between observed stand density and its theoretical maximum, describes the intensity of competition acting in the stand, and can be linked to specific stand developmental stages (Smith and Long, 2001). The maximum SDI for Norway spruce in the Paneveggio-Pale di San Martino Natural Park was calculated as 1380 from a dataset of 291 sample plots already available (Castagneri et al., 2008). We computed percent relative density in the two permanent plots for both inventory years as the ratio between observed and maximum SDI. We also computed mortality rates on an annual basis.

We determined the year of death of log and snags (decay classes 1 and 2) by cross-dating and rounded to the nearest decade. Logs and snags mortality causes were classified as follows:

- allogenic: logs from windthrow (uprooted or snapped trees with marked fracture and splintering);

- autogenic and unknown: logs from snags (trees that died standing and after some time fell on the ground) and snags with no evidence of primary mortality agents (Dobbertin, 2005). 
Table I. Decay class system for coarse woody debris elements.

\begin{tabular}{|c|c|c|c|}
\hline & Snag & $\log$ & Stump \\
\hline 1 & $\begin{array}{l}\text { Complete or partial bark, } \\
\text { most of the branches intact, } \\
\text { hard wood }\end{array}$ & $\begin{array}{l}\text { Bark intact, small branches } \\
\text { present, shape round, wood } \\
\text { texture intact, log elevated on } \\
\text { support point or slightly } \\
\text { sagging }\end{array}$ & $\begin{array}{c}\text { Bark intact, texture intact, } \\
\text { original surface cut and } \\
\text { original color }\end{array}$ \\
\hline 2 & $\begin{array}{c}\text { Partial/almost } \\
\text { absent bark, no } \\
\text { twigs, hard wood }\end{array}$ & $\begin{array}{c}\text { Trace of bark, no twigs } \\
\text { shape round, wood hard, texture in } \\
\text { large pieces, log sagging near } \\
\text { the ground }\end{array}$ & $\begin{array}{l}\text { Bark almost intact, texture } \\
\text { partly soft (in the outermost } \\
\text { part), original surface } \\
\text { cut and original color, } \\
\text { color }\end{array}$ \\
\hline 3 & $\begin{array}{c}\text { No bark, no twigs, } \\
\text { wood hard to soft } \\
\text { (soft sapwood }<70 \% \text { ) }\end{array}$ & $\begin{array}{l}\text { No bark, no twigs, shape } \\
\text { round to oval, wood hard to soft, } \\
\text { texture with blocky pieces, all } \\
\text { of log on the ground }\end{array}$ & $\begin{array}{l}\text { Trace of bark, texture in } \\
\text { large pieces, surface cut } \\
\text { original but decay spread } \\
\text { in most of the stump, } \\
\text { color becoming brown }\end{array}$ \\
\hline 4 & $\begin{array}{c}\text { No bark, no twigs, } \\
\text { wood hard to soft } \\
\text { (soft sapwood }>70 \% \text { ) }\end{array}$ & $\begin{array}{c}\text { No bark, no twigs, oval shape, } \\
\text { soft and powdery wood structure, } \\
\text { log completely sagging } \\
\text { on the ground }\end{array}$ & $\begin{array}{l}\text { Bark absent, texture soft } \\
\text { and powdery, surface cut almost } \\
\text { absent ad color brown }\end{array}$ \\
\hline
\end{tabular}

Table II. Stand characteristics (1993 and 2005).

\begin{tabular}{lccccccc}
\hline Plot & $\begin{array}{c}\text { Living } \\
\text { trees } \\
\mathrm{N} \mathrm{ha}^{-1}\end{array}$ & $\begin{array}{c}\text { Volume living } \\
\text { trees } \\
\left(\mathrm{m}^{3} \mathrm{ha}^{-1}\right)\end{array}$ & $\begin{array}{c}\text { Basal } \\
\text { area } \\
\left(\mathrm{m}^{2} \mathrm{ha}^{-1}\right)\end{array}$ & $\begin{array}{c}\text { Mean } \\
\text { diameter } \\
(\mathrm{cm})\end{array}$ & $\begin{array}{c}\text { Mean } \\
\text { height } \\
(\mathrm{m})\end{array}$ & $\begin{array}{c}\text { SDI } \\
\text { Relative } \\
\text { density } \\
\%\end{array}$ \\
\hline Plot VB1 (1993) & 474 & 725.7 & 54.8 & 38.4 & 29.7 & 935 & 67.7 \\
Plot VB1 (2005) & 466 & 841.4 & 63.3 & 41.6 & 30.8 & 1051 & 76.2 \\
Plot VB2a (1993) & 584 & 829.6 & 63.2 & 37.1 & 28.0 & 1058 & 76.7 \\
Plot VB2a (2005) & 513 & 914.5 & 69.2 & 41.5 & 29.6 & 1114 & 80.8 \\
\hline
\end{tabular}

Mortality induced by competition or other unknown were partitioned in two classes: (i) trees showing a growth decline before death, or suppressed trees characterized by very narrow rings during all their life and (ii) trees without evident signs of growth decline before death (Bigler and Bugmann, 2003).

\section{RESULTS}

\subsection{Stand structure}

Tree density was respectively 466 (Plot VB1) and 513 (Plot VB2a) trees $\mathrm{ha}^{-1}$ (Tab. II). Standing volume was respectively 841.4 and $914.5 \mathrm{~m}^{3} \mathrm{ha}^{-1}$. In 2005 the tree size distributions were unimodal (Castagneri et al., 2008) but didn't have a normal distribution (Shapiro-Wilk test). Density slightly decreased in both plots between the two measurements $(-1.7 \%$ in Plot VB1 and $-12.1 \%$ in Plot VB2a), high and medium-low diameter classes experienced increased and reduced frequencies respectively. The size distribution has not changed across time in both plots $(P>0.05)$. Size distribution differences between the two plots were not significant in year $2005(P>0.05)$.

We were able to determine the age at a height of $50 \mathrm{~cm}$ of $94.9 \%$ of the individuals. Stem and root rot was the main obstacle to age determination. The age structure (Fig. 1) pinpointed the time of establishment of the current stands: about $200 \mathrm{y}$ before present in plot VB1 and about $220 \mathrm{y}$ in plot VB2a.
Table III. Volume of snags, logs and stumps in the two plots (2005).

\begin{tabular}{cccccc}
\hline Plot & $\begin{array}{c}\text { Snags } \\
\left(\mathrm{m}^{3} \mathrm{ha}^{-1}\right)\end{array}$ & $\begin{array}{c}\text { Logs } \\
\left(\mathrm{m}^{3} \mathrm{ha}^{-1}\right)\end{array}$ & $\begin{array}{c}\text { Stumps } \\
\left(\mathrm{m}^{3} \mathrm{ha}^{-1}\right)\end{array}$ & $\begin{array}{c}\text { Total CWD } \\
\left(\mathrm{m}^{3} \mathrm{ha}^{-1}\right)\end{array}$ & $\begin{array}{c}\text { CWD/living } \\
\%\end{array}$ \\
\hline 1 & 5.4 & 4.4 & 17.8 & 27.6 & 3.3 \\
2 & 53.6 & 19.9 & 6.1 & 79.6 & 8.7 \\
\hline
\end{tabular}

The establishment period after the disturbance lasted approximately one century in both plots. There were some very old individuals in both plots, the oldest ones being 279 and $447 \mathrm{y}$ old in plot VB1 and VB2a respectively.

\subsection{CWD profile}

In 2005 the total volume of CWD was $27.6 \mathrm{~m}^{3} \mathrm{ha}^{-1}$ in plot VB1 and $79.6 \mathrm{~m}^{3} \mathrm{ha}^{-1}$ in plot VB2a (Tab. III). Stumps (exclusively of man-made origin in plot VB1 and almost exclusively so in plot VB2a) had an irregular diameter distribution, ranging from 15 to $70 \mathrm{~cm}$ in plot VB1 and from 10 to $100 \mathrm{~cm}$ in plot VB2a, with a modal value of $40 \mathrm{~cm}$ in both plots (Fig. 2). Snags had reverse J-shaped distribution in plot VB2a, while they were scarce in plot VB1. Logs showed a unimodal distribution in both plots with a modal value of $15 \mathrm{~cm}$ in plot VB1 and $20 \mathrm{~cm}$ in plot VB2a. Size distribution of snags, logs 

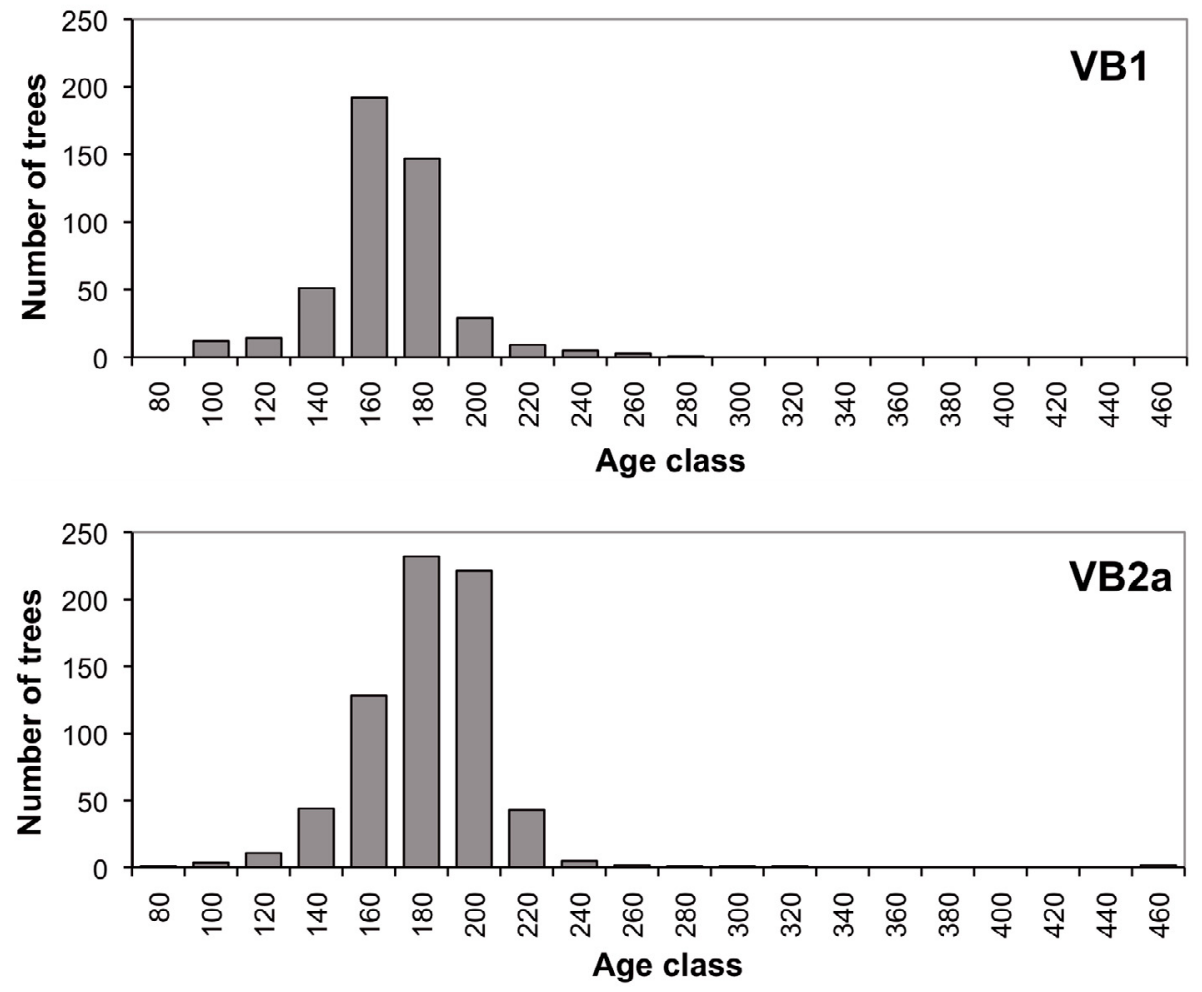

Figure 1. Age structure in the two plots (2005).
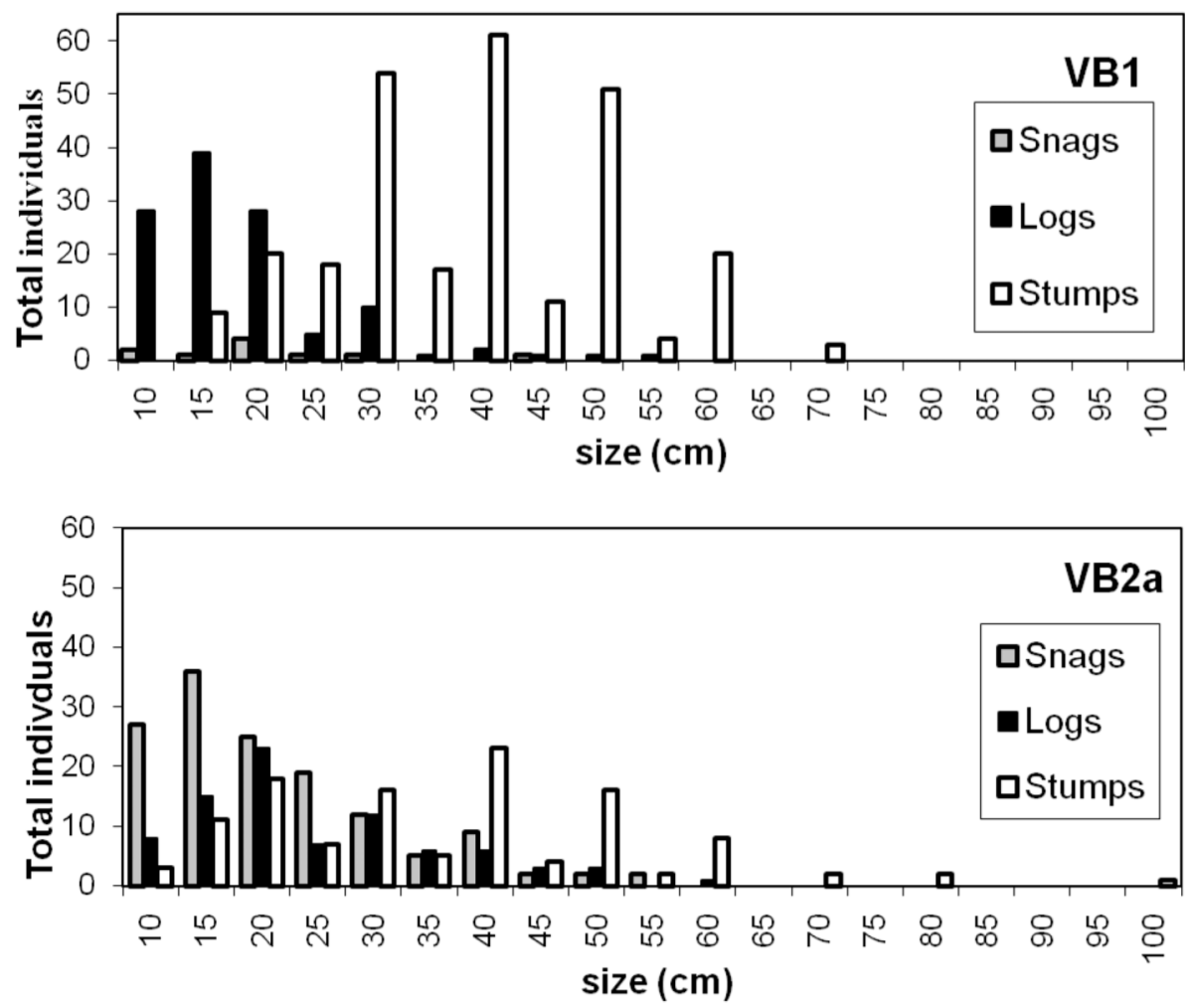

Figure 2. Size class distribution for the three CWD types (snags, logs and stumps) in the two plots (2005). 


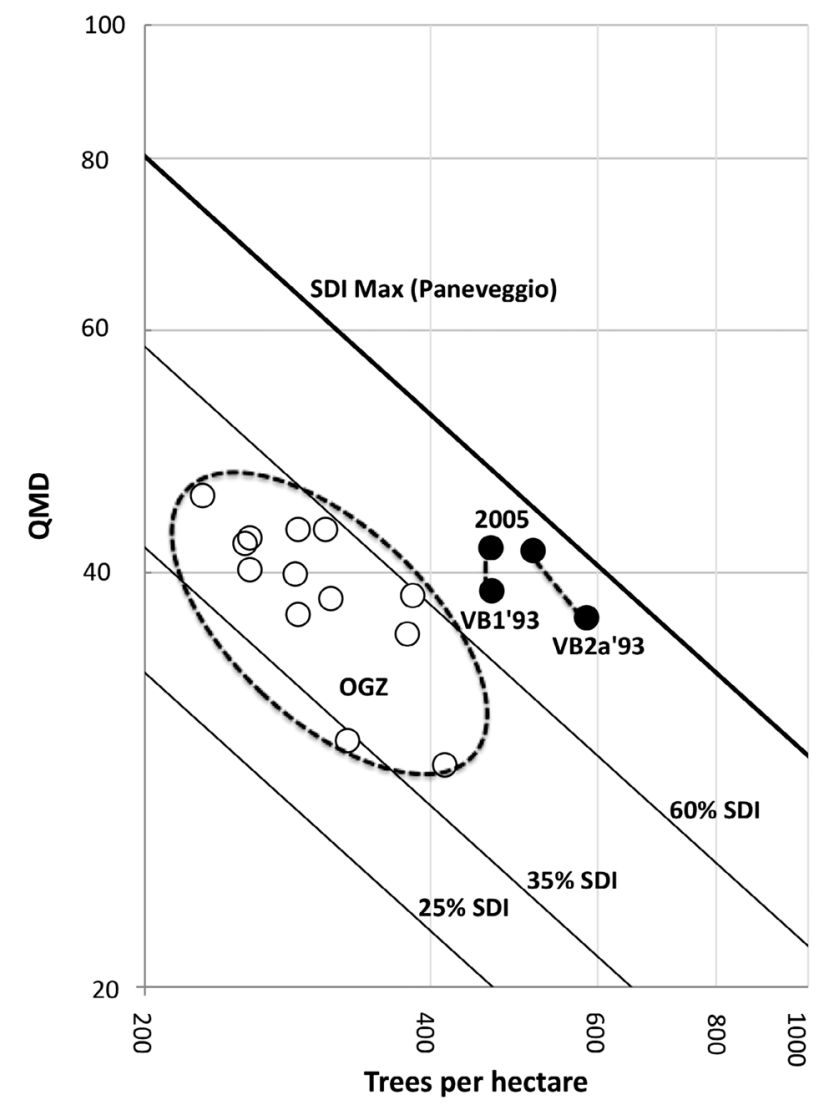

Figure 3. Size (QMD: quadratic mean diameter)-density relationships for the studied plots (1993 and 2005) and for some subalpine, old-growth Norway spruce forest in central Europe. Solid dots represent the Valbona plots respectively in 1993 and in 2005. VB2a is currently above $80 \%$ of the SDI that represents the biological carrying capacity of the site. VB1 is very close to this threshold. Empty dots represents size-density pairs for central European old-growth stands (see Tab. V). The relative density in old-growth stands ranges between 35 and $60 \%$ (OGZ: old-growth zone) suggesting that oldgrowth stage processes occur after a reduction of competition intensity due to both autogenic and allogenic disturbances

and stumps were significantly different from that of live trees in both plots $(p<0.05)$ taking into account that CWD size were measured in part of the trunk different form the dbh and the original trunk can produce more than one log resulting in a potential overestimation of this CWD type. CWD volume amounted to $3.3 \%$ of living tree volume in plot VB1 and $8.7 \%$ in plot VB2a (Tab. II). The volume of stumps was relevant in plot VB1, where they represented $64.5 \%$ of the total CWD volume, but scarce in plot VB2a (7.7\%). On the other hand, the volume of snags was relevant in plot VB2a, where they accounted for more than $67 \%$ of the CWD total volume. The $\operatorname{logs}$ represented $15.9 \%$ and $25.0 \%$ of the total CWD volume respectively in plot VB1 and VB2a. We assume that logs were over-represented in plot VB1, due to the presence of many short logs from a 1993 thinning.

Regarding decay class, we detected opposite trends between stumps, on one side, and snags and logs on the other
Table IV. CWD type and decay stage (\%) in the two plots (2005).

\begin{tabular}{lcccccc}
\hline & \multicolumn{3}{c}{ Plot 1 } & \multicolumn{3}{c}{ Plot 2 } \\
\hline Decay stage & Snags & Logs & Stumps & Snags & Logs & Stumps \\
\hline 1 & 60.9 & 29.0 & 0.4 & 88.4 & 31.8 & 0.0 \\
2 & 39.1 & 71.0 & 15.7 & 8.7 & 52.6 & 2.8 \\
3 & 0.0 & 0.0 & 18.7 & 1.4 & 13.3 & 29.9 \\
4 & 0.0 & 0.0 & 65.3 & 1.4 & 2.4 & 67.3 \\
\hline
\end{tabular}

(Tab. IV). Most of the stumps in both plots were in classes 3 and 4, i.e., the most decayed ones (84.0\% in plot VB1 and $97.2 \%$ in plot VB2a). On the other hand, $100.0 \%$ of the snags in plot VB1 and $97.2 \%$ in plot VB2a were in the lower decay classes (1 and 2). There was a higher incidence of snags in class 1 in plot VB2a (88.4\%) than in plot VB1 (60.9\%). If compared to snags, logs generally showed a more advanced decay status: class 2 was the most represented one in both plots (71.0\% and $52.6 \%$ of total logs respectively).

\subsection{Competition and mortality}

SDI (2005) was 1051 in plot VB1 and 1114 in plot VB2a. The log-slope of the self-thinning trajectory for the study period (1993-2005) was -4.802 in plot VB1, and -1.139 in plot VB2a (Fig. 3). In the last decade relative density increased in plot VB1 from 67.7 to $76.1 \%$ and in plot VB2a from 76.7 to $80.8 \%$ (Tab. I).

Mortality rate was $0.21 \% \mathrm{y}^{-1}$ in plot VB1 and $1.01 \% \mathrm{y}^{-1}$ in plot VB2a. In plot VB1 living biomass increased with very limited mortality, while plot VB2a suffered mortality that was mainly concentrated on the smaller and intermediate diameter classes (Fig. 4a).

We analyzed mortality dynamics in plot VB2a only, because sample size in plot VB1 was insufficient. In plot VB2a the date of death was successfully determined for $70 \%$ of the tree samples $(n=179)$. The earliest identified year of death belonged to the 1920 decade, while more than $55 \%$ of the tree death was observed in the decades 1970 and 1980 (Fig. 5).

The causes of death were mainly autogenic or unknown $(81 \%)$. Allogenic mortality was exclusively concentrated in the last decade (2000) and was due to wind or to wind-snow (snapped or uprooted trees); we didn't find any biotic primary mortality agents (e.g. insects and pathogens). The autogenicunknown mortality involved trees with a dbh ranging from 10 to $55 \mathrm{~cm}$, but was mainly concentrated in smaller diameters. Allogenic mortality had a higher incidence in dbh classes 30 $60 \mathrm{~cm}$ (Fig. 4b).

Most of the trees (54.8\%) defined as competition-induced or unknown mortality died after a perceptible decline or chronic slow growth observed in the tree-ring series (Bigler and Bugmann, 2003). Nevertheless, other trees died while growing at the normal rate with no indication of impeding mortality in the tree-ring patterns.

\section{DISCUSSION}

The two permanent plots showed some common characteristics: both established (about $200 \mathrm{y}$ ago plot VB1 and $220 \mathrm{y}$ 
Table V. Stand characteristics for some subalpine Norway spruce old-growth forest from the Carpathians, the Tatra mountains and from the Valbona forest Reserve in Paneveggio (2005). In all the stands the lowest measured dbh was $10 \mathrm{~cm}$ (density and mean dbh data from Valbona Reserve were harmonized according to this threshold). Data from Babia Gora 1, Polana and Sumava NP are means from a network of sampling plots. The other data are from individual permanent plots.

\begin{tabular}{|c|c|c|c|c|c|c|c|c|c|c|c|}
\hline & $\begin{array}{l}\text { Volume } \\
\left(\mathrm{m}^{3} \mathrm{ha}^{-1}\right)\end{array}$ & $\begin{array}{c}\text { Basal } \\
\text { area } \\
\left(\mathrm{m}^{2} \mathrm{ha}^{-1}\right.\end{array}$ & $\left(\mathrm{N} \mathrm{ha}^{-1}\right)$ & $\begin{array}{c}\text { Mean } \\
\text { dbh } \\
(\mathrm{cm})\end{array}$ & $\begin{array}{l}\text { Volume } \\
\text { snags } \\
\left(\mathrm{m}^{3} \mathrm{ha}^{-1}\right)\end{array}$ & $\begin{array}{c}\text { Volume } \\
\text { logs } \\
\left(\mathrm{m}^{3} \mathrm{ha}^{-1}\right)\end{array}$ & $\begin{array}{c}\text { Volume } \\
\text { stumps } \\
\left(\mathrm{m}^{3} \mathrm{ha}^{-1}\right)\end{array}$ & $\begin{array}{l}\text { Total CWD } \\
\text { volume } \\
\left(\mathrm{m}^{3} \mathrm{ha}^{-1}\right)\end{array}$ & $\begin{array}{l}\text { CWD/live } \\
\text { trees } \\
\%\end{array}$ & $\begin{array}{c}\text { Total volume } \\
\text { living tree }+\mathrm{CWD} \\
\left(\mathrm{m}^{3} \mathrm{ha}^{-1}\right)\end{array}$ & Reference \\
\hline Babia Gora 1 & 407.0 & 36.4 & 258 & 42.4 & 58.5 & 72.6 & $*$ & 131.1 & 32.2 & 538,1 & (Holeksa, 2001) \\
\hline Babia Gora 2 & 387.2 & 35.3 & 255 & 42.0 & 54.4 & 76.0 & 6.0 & 136.4 & 35.2 & 523.6 & (Zielonka, 2006) \\
\hline Babia Gora 3 & 412.1 & 32.7 & 258 & 40.2 & 71.0 & 73.4 & 8.2 & 152.6 & 37.0 & 564.7 & (Zielonka, 2006) \\
\hline Babia Gora 4 & 511.2 & 37.4 & 230 & 45.5 & 73.8 & 110.1 & 9.2 & 193.1 & 37.8 & 704.3 & (Zielonka, 2006) \\
\hline Babia Gora 5 & 465.9 & 36.0 & 288 & 39.9 & 106.1 & 145.5 & 9.7 & 261.3 & 56.1 & 727.2 & (Zielonka, 2006) \\
\hline Babia Gora 6 & 540.3 & 38.7 & 378 & 36.1 & 58.3 & 78.8 & 4.5 & 141.6 & 26.2 & 681.8 & (Zielonka, 2006) \\
\hline Tatra Mountains 1 & 351.5 & 27.3 & 414 & 29.0 & 119.4 & 82.1 & 5.1 & 206.6 & 58.8 & 558.1 & (Zielonka, 2006) \\
\hline Tatra Mountains 2 & 306.9 & 23.4 & 327 & 30.2 & 185.3 & 88.2 & 8.9 & 292.4 & 95.5 & 599.3 & (Zielonka, 2006) \\
\hline Tatra Mountains 3 & 486.4 & 42.1 & 290 & 43.0 & 72.2 & 60.4 & 4.0 & 136.6 & 28.0 & 623.1 & (Zielonka, 2006) \\
\hline Tatra Mountains 4 & 622.3 & 44.6 & 383 & 38.5 & 90.7 & 104.5 & 8.1 & 203.3 & 32.3 & 825.6 & (Zielonka, 2006) \\
\hline Tatra Mountains 6 & 453.8 & 36.1 & 314 & 38.3 & 92.4 & 92.1 & 7.1 & 191.5 & 42.2 & 645.3 & (Zielonka, 2006) \\
\hline Polana & 500.0 & 41.0 & 290 & 37.3 & 48.6 & 94.9 & $*$ & 143.5 & 28.7 & 643,5 & (Holeksa et al., 2007) \\
\hline Sumava NP 1 & 351.0 & 32.0 & 131 & 53.0 & 196.0 & 115.0 & $*$ & 311.0 & 88.6 & 662.0 & (Svoboda and Pouska, 2008) \\
\hline Sumava NP 2 & 447.0 & 45.0 & 310 & 43.0 & 96.0 & 60.0 & $*$ & 156.0 & 34.9 & 603.0 & (Svoboda and Pouska, 2008) \\
\hline Valbona 1 & 841.4 & 63.2 & 463 & 41.6 & 5.4 & 4.4 & 17.8 & 27.6 & 3.3 & 868,9 & This study \\
\hline Valbona $2 \mathrm{a}$ & 945.3 & 71.2 & 489 & 42.9 & 53.6 & 19.9 & 6.1 & 79.6 & 8.4 & 1025.0 & This study \\
\hline
\end{tabular}

* Data from stumps not available (snags and stumps are presented together).

plot VB2a) after a shelterwood felling and were respectively managed until 1983 (plot VB1) and about 1950 (plot VB2a) (Motta et al., 1999). Both were monolayered and were overstocked if compared with central European Norway spruce old-growth forests (Fig. 3; Tab. V).

A first difference between the two plots was the CWD profile (Stokland, 2001; Woodall and Nagel, 2006). Plot VB1 was poor in CWD, there were stumps in all decay classes (even if only $16.1 \%$ in the classes 1-2) and there were no snags and logs in classes 3-4. Plot VB2a was richer in CWD, the stumps showed a high decay rate (there were no stumps in the decay class 1 and very few in class 2), there were logs in all decay classes (52.6\% in class 2$)$ and so were snags, even if more than $88 \%$ in class 1 . Even if Norway spruce is considered very susceptible to windthrow because of its shallow root system, uprooted trees were absent in plot VB1 and rare in plot VB2a. Until the last decade mortality was confined to the suppressed trees and dead trees only reached the ground $(\operatorname{logs})$ after a first stage as a snag. This explains why there are only a few logs in the first decay class (Motta et al., 2006). The rate of CWD accumulation was slow (the total amount is 27.6 and $79.6 \mathrm{~m}^{3} \mathrm{ha}^{-1}$ after about 22 and $55 \mathrm{y}$ from the cessation of silvicultural interventions) as compared, for example, to that observed in mixed mountain forests (Motta et al., 2008).

Another difference was represented by the intensity of competition (Castagneri et al., 2010) and, consequently, the mortality rate. At the beginning of the study period, relative density in both plots was already above the $60 \%$ threshold (Tab. I; Fig. 3), which represents complete resource exploitation and marks the onset of the self-thinning process (Drew and Flewelling, 1979). The size-density trajectory (Fig. 3) for the last decade in plot VB1 showed a period of increase in mean tree size without density-related mortality (annual mortality rate $=0.21 \%$ ) as a consequence of the last thinning. Plot VB2a showed an increase in mean tree size and reduction in density (annual mortality rate $=1.01 \%$ ) but, in the same time, due to the size increment, reached the $80 \%$ of maximum SDI, meaning that the biological carrying capacity of the site was nearly totally exploited (Long and Shaw, 2005). In plot VB2a competition for resources was extreme and has been high for an extended period. In this plot the date of tree death showed that the autogenic-unknown mortality reached the maximum in the decades 1970 and 1980 (Fig. 5), and subsequently declined (1990 and, even more, 2000). In the last decade overall mortality was higher than in the previous decade because of the onset of allogenic mortality, that has involved dominant and co-dominant trees (Fig. 4b). We found some discrepancies for autogenic-unknown mortality: a few trees according to crown assessment, were alive in 1993 and dead in 2005 but their last cross-dated tree-ring was formed before 1993. Autogenic-unknown mortality dates should be to be taken with caution, because the formation of tree rings may stop for years or even for decades prior to mortality (Cherubini et al., 2002).

Both plots have developed very few old-growth characteristics: even if the average size of the trees is higher if compared with the old-growth ones (Fig. 3), this is the result of a different size distribution. The studied plots have an "unimodal" distribution while a true old-growth is expected to have a "negative exponential" distribution. As a consequence the average size value is high, if compared with a true old-growth, but both stands lack or have very few very large trees that are one of the characteristics of an old-growth. The same is for the CWD: large piece of CWD are mainly stumps (Fig. 2) and 


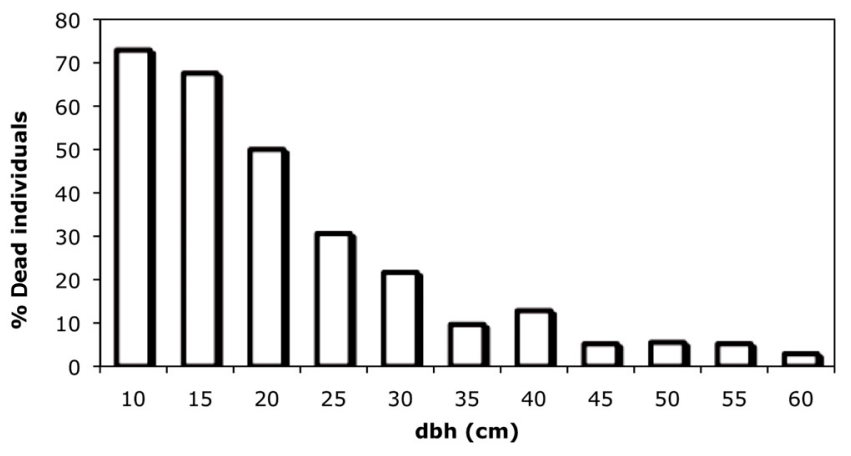

口Snags $\square$ Logs (from snags) $\mathbf{D}$ Logs (windthrow)

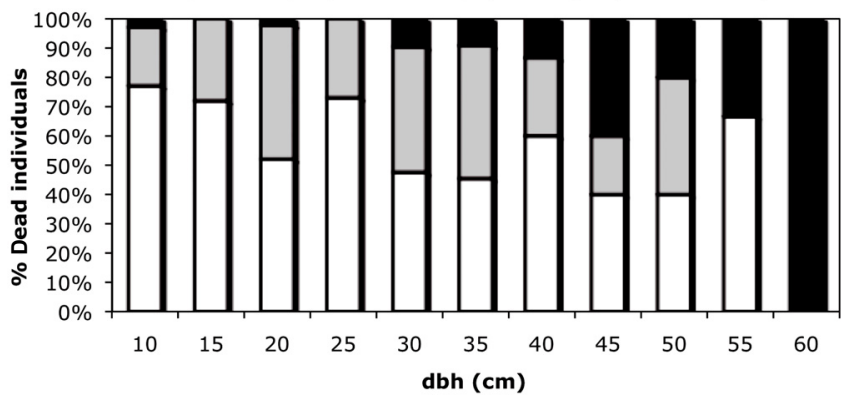

Figure 4. Diameter distribution (a) and incidence of mortality (both snags and logs) in the different size classes (b) in plot VB2a (2005).

the quantity and the quality (stage of decay) of the CWD is not comparable with the old-growth (Tab. IV). According to the structure, CWD profile, competition intensity and mortality rate, plot VB1 was classified as being at the end of the stem exclusion stage, while plot VB2a was assigned to a initial transition stage between stem exclusion and understory reinitiation (Oliver and Larson, 1996). In the next decades, VB1 will probably follow the same dynamics recently observed in VB2a (increment of competition and autogenic mortality), while plot VB2a will continue the structural re-organisation that is leading it from a monolayered to a multilayered structure. During such transition, allogenic disturbances will increase their importance, and the decrement of tree density will lead to QMD/density relationships more and more close to those observed for subalpine Norway spruce in a true oldgrowth stage (Tab. V). This process results in a progressive accumulation of gaps as the stand gets older, so that the stand development trajectory drops below the maximum density line resulting in a SDI decline (Smith and Long, 2001). The decrement of the intensity of the competition is due to the fact that the death of old and large trees may exceed the capability of lateral growth of surviving crowns and ingrowth in overmature stands (Zeide, 1995). There are also other ecophysiological explanations for the age-related decline of radial growth (Binkley et al., 2002).

In any case, the time requested to develop a multilayered structure is still long. Besides the further creation of new gaps, that cannot be accurately foretold, the establishment and growth of new cohorts will be postponed by many decades for the following reasons:

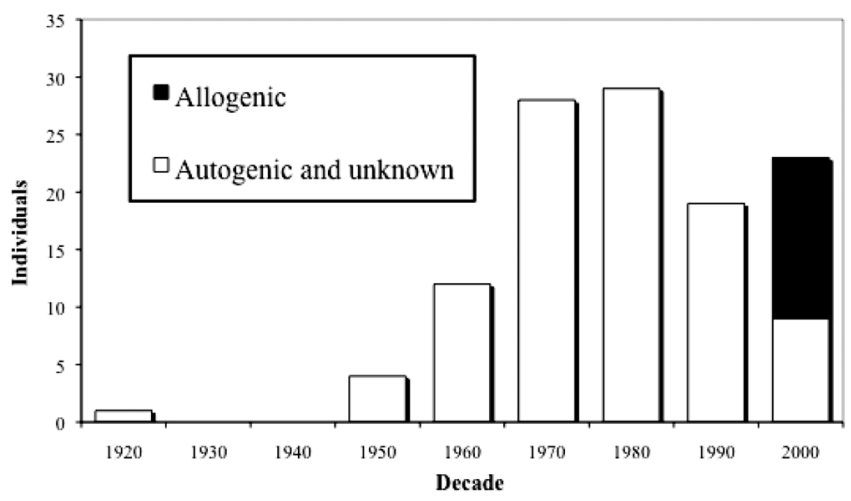

Figure 5. Decade and cause of death for cross-dated snags and logs in decay classes 1 and 2 in plot VB2a (2005).

(1) Seed production is irregular, with adequate quantity and quality for seedling establishment only after a mast year, that occurs every 8-10 y on average (Mencuccini et al., 1995).

(2) Seedling establishment requires a favorable seedbed. Different types of microsites, e.g., CWD, mounds, and uprooting pits, are vital for regeneration establishment and early growth (Motta et al., 2006). However, microsite diversity and CWD quantity and quality are greatly reduced in managed stands. Besides, the process of wood decay in subalpine Norway spruce forests is very slow (Holeksa et al., 2008; Storaunet and Rolstad, 2002), so that it will take many more decades to develop a decay rate continuity favorable to seedling establishment and comparable to those of true oldgrowth forests.

(3) Early regeneration growth is slow. Norway spruce in Paneveggio requires an average of $18 \mathrm{y}$ to reach $50 \mathrm{~cm}$ height and more than $40 \mathrm{y}$ to reach $130 \mathrm{~cm}$ height (Motta et al., 2002; Piussi, 1976).

The legacies of past management are dense stands with higher resistance to small scale allogenic disturbances, low mortality rate, limited CWD accumulation and unfavorable conditions for natural regeneration establishment. Other potential legacies, such as old logging damages that could have enhanced the spread of decay fungi (Vasiliauskas, 2001) and monolayered structure that could be more vulnerable to wind disturbances (Zeng et al. 2010), at the present have no evident consequences in the two studied plots. As a consequence we expect that these previously managed stands will reach more advanced stages of development far later than natural stands.

In previously managed, subalpine Norway spruce forests of the Alps, structure, CWD profile, competition and mortality were useful parameters to delineate the present development stage, as compared to the old-growth one. Further studies documenting natural disturbance regimes and associated stand structures and dynamics of late successional stages are much needed to refine silvicultural systems meant to develop and maintain old-growth characteristics (Long, 2009). For this reason, it is crucial to develop a network of forest reserves in previously managed forests that have been withdrawn from regular management, in order for natural processes to be allowed 
to take place and to provide a reference for ordinary managed forests (Bauhus et al., 2009; Brang, 2005; Motta, 2002).

Acknowledgements: We thank the "Autonomous Province of Trento" and the "Parco Naturale Paneveggio-Pale di S. Martino" for logistic support. Thanks to Prof. Pietro Piussi for his helpful comments on the manuscript.

\section{REFERENCES}

Bauhus J., Puettmann K., and Messier C., 2009. Silviculture for oldgrowth attributes. For. Ecol. Manage. 258: 525-537.

Bigler C. and Bugmann H., 2003. Growth-dependent tree mortality models based on tree rings. Can. J. For. Res. 33: 210-221.

Binkley D., Stape J.L., Ryan M.G., Barnard H.R., and Fownes J., 2002. Age-related decline in forest ecosystem growth: an individual-tree, stand-structure hypothesis. Ecosystems 5: 58-67.

Brang P., 2005. Virgin forests as a knowledge source for central European silviculture: reality or myth? For. Snow Landsc. Res. 79: 19-32.

Castagneri D., Lingua E., Vacchiano G., Nola P., and Motta R., 2010. Diachronic analysis of individual-tree mortality in a Norway spruce stand in the eastern Italian Alps. Ann. For. Sci. 67: 304.

Castagneri D., Vacchiano G., Lingua E., and Motta R., 2008. Analysis of intraspecific competition in two subalpine Norway spruce (Picea abies (L.) Karst.) stands in Paneveggio (Trento, Italy). For. Ecol. Manage. 255: 651-659.

Cherubini P., Fontana G., Rigling D., Dobbertin M., Brang P., and Innes J.L., 2002. Tree-life history prior to death: two fungal root pathogens affect tree-ring growth differently. J. Ecol. 90: 839-850.

Dobbertin M., 2005. Tree growth as indicator of tree vitality and of tree reaction to environmental stress: a review. Eur. J. For. Res. 124: 319 333.

Drew J.T. and Flewelling J.W., 1979. Stand density management: an alternative approach and its application to Douglas fir plantations. For. Sci. 25: 518-532.

Foster D., Swanson F., Aber J., Burke I., Brokaw N., Tilman D., and Knapp A., 2003. The importance of land-use legacies to ecology and conservation. BioScience 53: 77-88.

Foster D.R., Orwig D.A., and McLachlan J.S., 1996. Ecological and conservation insights from reconstructive studies of temperate oldgrowth forests. Trends Ecol. Evol. 11: 419-424.

Franklin J.F., Mitchell R.J., and Palik B.A., 2007. Natural disturbance and stand development principles for ecological forestry, Gen. Tech. Rep. NRS-19, USDA, Northern Research Station, Newtown Square, PA, 44 p.

Hammer Ø., Harper D.A.T., and Ryan P.D., 2001. PAST: Paleontological statistics software package for education and data analysis. Palaeontologia Electronica 4: 1-9.

Holeksa J., Saniga M., Szwagrzyk J., Dziedzic T., Ferenc S., and Wodka M., 2007. Altitudinal variability of stand structure and regeneration in the subalpine spruce forests of the Pol'ana biosphere reserve, Central Slovakia. Eur. J. For. Res. 126: 303-313.

Holeksa J., Zielonka T., and Zywiec M., 2008. Modeling the decay of coarse woody debris in a subalpine Norway spruce forest of the West Carpathians, Poland. Can. J. For. Res. 38: 415-428.

Holeksa V.J., 2001. Coarse woody debris in a Carpathian subalpine spruce forest. Forstw. Cbl. 120: 256-270.

Keeton W.S., 2006. Managing for late-successional/old-growth characteristics in northern hardwood-conifer forests. For. Ecol. Manage. 235: $129-142$.

Kohm K.A. and Franklin J.F., 1997. Creating a forestry for the 21st century: the science of ecosystem management, Island Press, Washington D.C., $475 \mathrm{p}$.

Long J.N., 2009. Emulating natural disturbance regimes as a basis for forest management: A North American view. For. Ecol. Manage. 257: $1868-1873$.

Long J.N. and Shaw J.D., 2005. A density management diagram for evenaged ponderosa pine stands. West. J. Appl. For. 20: 205-215.
Marage D. and Lemperiere G., 2005. The management of snags: A comparison in managed and unmanaged ancient forests of the Southern French Alps. Ann. For. Sci. 62: 135-142.

Mencuccini M., Piussi P., and Zanzi Sulli A., 1995. Thirty years of seed production in a subalpine Norway spruce forest: patterns of temporal and spatial variation. For. Ecol. Manage. 76: 109-125.

Motta R., 2002. Old-growth forests and silviculture in the Italian Alps: the case-study of the strict reserve of Paneveggio (TN). Plant Biosyst. 136: 223-232.

Motta R., Berretti R., Lingua E., and Piussi P., 2006. Coarse woody debris, forest structure and regeneration in the Valbona Forest Reserve, Paneveggio, Italian Alps. For. Ecol. Manage. 235: 155-163.

Motta R., Maunaga Z., Berretti R., Castagneri D., Lingua E., and Meloni F., 2008. La Riserva forestale di Lom (Repubblica di Bosnia Erzegovina): descrizione, caratteristiche, struttura di un popolamento vetusto e confronto con popolamenti stramaturi delle Alpi italiane. Forest@ 5: 100-111.

Motta R., Morales M., and Nola P., 2006. Human land-use, forest dynamics and tree growth at the treeline in the Western Italian Alps. Ann. For. Sci. 63: 739-747.

Motta R., Nola P., and Piussi P., 1999. Structure and stand development in three subalpine Norway spruce (Picea abies (L.) Karst.) stands in Paneveggio (Trento, Italy). Glob. Ecol. Biogeogr. 8: 455-473.

Motta R., Nola P., and Piussi P., 2002. Long-term investigations in a strict forest reserve in the eastern Italian Alps: spatio-temporal origin and development in two multi-layered subalpine stands. J. Ecol. 90: 495-507.

Oliver C.D. and Larson B.C., 1996. Forest stand dynamics. John Wiley $\&$ Sons, New York, $520 \mathrm{p}$.

Piussi P., 1976. Observations sur l'âge et la croissance en diamètre de certains épicéas de haute montagne. Beih. Z. Schweiz. Fortsvereins, 57: 66-73.

Reineke L.H., 1933. Perfecting a Stand-Density Index for even-aged forests. J. Agric. Res. 46: 627-638.

Shaw J.D., 2000. Application of stand density index to irregularly structured stands. West. J. Appl. For. 15: 40-42.

Smith F.W. and Long J.N., 2001. Age-related decline in forest growth: an emergent property. For. Ecol. Manage. 144: 175-181.

Sollins P., 1982. Input and decay of coarse woody debris in coniferous stands in western Oregon and Washington. Can. J. For. Res. 12: $18-28$.

Stokland J.N., 2001. The coarse woody debris profile: an archive of recent forest history and an important biodiversity indicator. Ecol. Bull. 49: $71-83$.

Storaunet K.O. and Rolstad J., 2002. Time since death and fall of Norway spruce logs in old-growth and selectively cut boreal forest. Can. J. For. Res. 32: 1801-1812.

Svoboda M. and Pouska V., 2008. Structure of a Central-European mountain spruce old-growth forest with respect to historical development. For. Ecol. Manage. 255: 2177-2188.

Vandekerkhove K., De Keersmaeker L., Menke N., Meyer P., and Verschelde P., 2009. When nature takes over from man: Dead wood accumulation in previously managed oak and beech woodlands in North-western and Central Europe. For. Ecol. Manage. 258: 425435.

Vasiliauskas R., 2001. Damage to trees due to forestry operations and its pathological significance in temperate forests: a literature review. Forestry 74: 319-336.

Woodall C.W. and Nagel L.M., 2006. Coarse woody type: a new method for analyzing coarse woody debris and forest change. For. Ecol. Manage. 227: 115-121.

Zeide B., 1995. A relationship between size of trees and their number. For. Ecol. Manage. 72: 265-272.

Zeng H., Garcia-Gonzalo J., Peltola H., and Kellomäki S., 2010. The effects of forest structure on the risk of wind damage at a landscape level in a boreal forest ecosystem. Ann. For. Sci. 67: 111.

Zielonka T., 2006. Quantity and decay stages of coarse woody debris in old-growth subalpine spruce forests of the western Carpathians, Poland. Can. J. For. Res. 36: 2614-2622. 